\section{Interaction Between Strategy and Organizational Performance: The Influence of Family Management}

\author{
Ieda Margarete Oro ${ }^{\dagger}$ \\ Universidade do Oeste de Santa Catarina \\ Carlos Eduardo Facin Lavarda ${ }^{\Omega}$ \\ UFSC
}

\section{ABSTRACT}

This article aims to analyze how occurs the interaction between business strategy and organizational performance in family firms. The research is classified as descriptive, with a qualitative approach, operationalized by the case study procedure. Data were collected through semi-structured interviews, documents and notices. Interviews were conducted with key informants and core family run. Evidence collected in the company searched, show that the business strategy with entrepreneurial attitude is characterized by the differentiation strategy (brand management) and product innovation (creation and development of new products) driven by family values disseminated within the organization. The results indicate that entrepreneurial orientation and family influence plays an important role for the realization of structural and strategic fit and, in turn, to the achievement of organizational performance.

Keywords: Business strategy; Performance; Family management.

\section{INTRODUCTION}

Family and family owned companies are common among publicly traded companies in the world, representing $90 \%$ in the US (BURKART; PANUNZI; SHLEIFER, 2003). In Brazil, according to Sebrae (2005), there are between 6 and 8 million enterprises, 90\% of them family businesses; however, the process of continuity of the family business is only $30 \%$ for second generation and $14 \%$ for third generation (VENTER; BOSHOFF; MAAS, 2005; NÓBREGA; HOFFMANN, 2014).

Among the main challenges are the company's growth and continuity of family control. To retain the majority stake and manage considering the longevity attribute was revealed by $76 \%$ of respondents to a survey conducted by KPMG (2014), with 125 family managers worldwide. Thus, studies have found that continuous family ownership can be efficient and create transgenerational value (CRUZ; NORDQVIST, 2010; ZELLWEGER; NASON; NORDQVIST, 2012; SCIASCIA; MAZZOLA; KELLERMANNS, 2014), if the resources are properly used (HABBERSHON; WILLIAMS, 1999), adopting a long-term perspective with defined strategic positioning (ZELLWEGER, 2007) and promoting strategic adjustment to achieve a superior performance (HIENERTH; KESSLER,2006; LINDOW; STUBNER; WULF,2010; LINDOW, 2013).

\author{
Corresponding author: \\ † Universidade do Oeste de Santa \\ Catarina (Unoesc) \\ E-mail: ieda.oro@unoesc.edu.br \\ $\Omega$ Universidade Federal de Santa Catarina \\ E-mail: elavarda@gmail.com \\ Received: 10/25/2015. \\ Revised: 05/17/2016. \\ Accepted: 05/17/2016. \\ Published Online: 12/01/2016.
}

DOI: http://dx.doi.org/10.15728/bbr.2017.14.5.3 
In the competitive environment, the innovation strategy emerges as a possibility of long-term survival, greater flexibility and adaptability to environmental requirements, as well as entrepreneurial characteristics (GONÇALVES, 2000; NÓBREGA; HOFFMANN, 2014; PADILLA; DIEGUEZ; MORENO, 2015). However, the strategic behavior of family managers that surrounds each generation may be different, proposing with this new configurations and new management models, suggesting the need for strategic adjustment. In this sense, studies have indicated that one way to obtain and sustain competitive advantage is through strategies that differentiate the company from its competitors, including differentiation (PORTER, 1980; ACQUAAH, 2013) and product innovation (SCHUMPETER, 1934; UTTERBACK; ABERNATHY, 1975; MILLER AND FRIESEN, 1982; DAVILA, EPSTEIN; SHELTON, 2007; SILVEIRA; OLIVEIRA, 2013).

Evidence from earlier studies indicate that companies with entrepreneurial attitude develop proactive management features, while companies with conservative orientation have reactive management feature, but both seek innovation, as well as family relationships can be a competitive advantage for the family business (ZAHRA 2005; CRAIG; DIBREL, 2006; KELLERMANNS et al., 2012). Innovation has been linked as essential for competitive advantage, however, "little is known about the consequences of family involvement in the determinants and on the dimensions of innovation and their relations" in family businesses (PADILLA; DIEGUEZ; MORENO, 2015, p. 1066). In addition, "the relationship between innovation and business performance has been greatly explored in the literature, at the theoretical level" (BRITO; BRITO; MORGANTI, 2009, p.5).

From this, the problem that presents itself for this research is how the interaction takes place between the business strategy with organizational performance in family businesses? The overall objective is to analyze how the interaction of business strategy occurs with organizational performance in family firms.

The strategic adjustment suggests that the alignment between corporate strategy and structure results in positive impact on performance (CHANDLER, 1962); consequently, companies should strive to achieve this alignment. Lindow, Stubner and Wulf (2010) found that the adjustment between strategy and structure was predominantly obtained by advocates and family businesses potentially retains its centralized structures, yet when they grow a strategic misfit occurs (DONALDSON, 2001).

The theoretical and empirical contribution of this study is based on the research gaps identified in the literature dealing with congruent themes (Strategy and Performance) from the perspective of Contingency Theory, especially the theoretical concept of strategic adjustment. It addresses the Family Management Model (property, family and Management/Enterprise) to characterize the case study.

\section{REVIEW OF LITERATURE AND RESEARCH PROPOSAL}

Among the forms of adjustment (fit) are the structural adjustment and the strategic fit. In the structural adjustment, organizational theorists point out that contingencies and structure fit for a positive effect on the company's performance (DONALDSON, 2001). In the strategic fit, Venkatraman and Camillus (1984) point out that the setting is a concept present in the process and formulation and implementation of the strategy, and that there are gaps in understanding of the concept depending on the schools of thought employed by the research. The strategic adjustment concept understands that organizations can improve their performance by pursuing an alignment between strategy and organizational structure (VENKATRAMAN, 1990 cited in LINDOW; STUBNER; 
WULF, 2010). In this regard, the setting is treated in three different forms: external alignment (strategy formulation), internal (strategy implementation) and integrated.

In adjustment (Fit) are present external factors considered essential to adapt to the competitive environment (PORTER, 1980; NAMAN; SLEVIN, 1993). The setting (Fit) internal "may take different names in the literature, such as implementation of the strategy, corporate and coherence cohesion." This arrangement means "mobilization of domestic, tangible or intangible resources, to implement the formulated strategy" (PRIETO; CARVALHO; FISCHMANN, 2009, p 319.). In the view of Drazin and Van de Ven (1985), the relationship between the context and the structure there is an intrinsic relationship, the combined selection approach with the interaction approach categorizes process variables and structure. Therefore, the setting (Fit) should be interpreted in two ways: first, as congruence between the structure and process variables that are highly correlated with the context, and secondly, such interaction for the particular variables.

Miller and Friesen (1982) suggest two models of business strategy: conservative and entrepreneur. In the conservative guidance model, innovation is encouraged from challenges and threats caused by factors linked to the surrounding, which can be linked to the company's operating market. Such challenges are brought to the decision by the controls that integrate information systems. The company that adopts the challenge to innovate need to have physical and human resources (skills and abilities) to deploy innovative projects.

Conservative companies or defenders have strict domain of product market. In top management, they are experts in the area of its operation, but do not tend to look outside of their domains to search for new opportunities. As a result of this narrow focus, these companies rarely need to make major adjustments in their technology, their structure or their methods of operation. Instead, dedicated primary care to improve the efficiency of their existing operations. Thus, this strategic type requires a highly centralized organizational structure to be intensely effective (LINDOW, 2013). Lindow (2013) investigated whether the strategic adjustment contributes to competitive advantage in family businesses and the influence of the family promotes performance. The study was based on a sample of 150 German family-owned companies. The results showed that the influence of the family has important implications for the achievement of the strategic adjustment and, with it, the creation of superior performance.

In the entrepreneurial orientation, innovation is seen as a vital and central element of the strategy. Miller and Friesen (1982) posit that companies are engaged with innovation projects, as this is constituted as a guideline in its business strategy. To do so, however, some factors must be considered. First, the control systems will prove to be effective to improve the quality of information and hence the decision making. Second, decisions about the future and sustainability should prove effective, as well as evaluating aware of strategies to protect themselves against excessive innovation. Third, when the environment is heterogeneous, differentiation and product innovation are positive factors for the model.

Innovation for Craig, Dibrell and Garret (2014) may or may not vary in complexity, ranging from changes in existing products, processes or services, as well as the introduction of new revolutionary technologies, whose characteristics provide exceptional performance, or altered the rules of the competitive domain. Padilla, Dieguez and Moreno (2015, p. 1067) argue that "the junction of family business and innovation has not been, however, a topic so well researched, as are missing each one individually and a comprehensive perspective to the impact of the family's influence on the dimensions and determinants of innovation and their connections".

Hambrick (1983) and Govindarajan (1988) point out that in the differentiation strategy; a firm seeks to be unique in their products with features that are widely valued 
by consumers. However, the use of strategic typologies (MINTZBERG, 1973; MILES; SNOW, 1978; PORTER, 1980; MILLER; FRIESEN, 1982) has been under criticism over time, due to a reduction of the range of combinations that the researcher could consider (HAMBRICK, 1983). In addition, a hybrid alternative (differentiation and costs) cannot be disregarded and it neither does it mean that the company does not have defined strategies (CARNEIRO; CAVALCANTI; SILVA, 1997).

In recent research on types of Porter's strategies, Acquaah (2011) has confirmed, in a study of 54 companies, that the cost of leadership and differentiation strategies are positively related to performance (return on assets and return on sales) in family businesses. The study of Almeida, Machado and Panhoca (2012) found that among companies that adopt the strategy of differentiation, the results suggest that they attach greater use of cost management practices. For Melo and Leone (2015), processing companies, located in the city of Mossoró-RN, positioning themselves to compete with priority differentiation strategies and leadership at the present cost advantage relative to its strategic position, i.e. in the differentiation of products and low manufacturing cost.

The influence of the family is characterized by the generation in charge and consequently by the family business management model (GERSICK et al., 1997; CRUZ; NORDQVIST, 2010). Regardless of the organization's control be with the owner or with the sons both are concerned with growth. The new generation instills new ideas and conceptions about management models, while the older generation tends to be more conservative with regard to decision-making, especially when they involve the family heritage. However, previous studies show that the involvement of next generation and performance is a inconclusive theme, with divergent results (BENNEDSEN et al., 2007; CASILLAS; MORENO; BARBERO, 2009; MOLLY, LAVEREN; DELOOF, 2010; KELLERMANNS et al. 2012; CRAIG; DIBRELL; GARRETT, 2014). The interaction between these various family groups, each dealing with their own problems and conflicts, there may be some interesting dynamics in business models, combining conservative and entrepreneurs.

Casillas, Moreno and Barbero (2009) analyzed the influence of three characteristics of family businesses (management level, non-family participation in management and involvement of next generation in business) business orientation and the role of environmental dynamism and hostility as moderator variables in this relationship. Kellermanns et al. (2012) investigated the influence of family relations and performance. The results indicate that the influence of the family can have positive and negative consequences for the company's performance. Craig, Dibrell and Garrett (2014) researched the influence of family, culture, family business and flexible planning systems to promote innovation and superior performance. The authors found evidence that the influence of the family focuses on culture and the flexibility impacts positively for innovative behavior.

Whereas business strategies contribute to increase organizational performance in family businesses, the theoretical proposition that guides this study is that the fit between the business strategy, the family-run model (property, family and management/ company) interferes positively on performance organizational.

\section{RESEARCH METHOD AND PROCEDURE}

This research is characterized as descriptive of the aims, case study about the procedures and qualitative approach to the research problem. The purpose of a case study is to know an entity and understand in depth the "how" and "why" of the occurrence of 
certain phenomena, showing their identity and their own characteristics, the aspects of interest to the researcher (YIN, 2010).

Because of the complexity of social studies, the research construct aims to identify the presence of observable variables and indicate how these events can be captured by the constitutive definitions, which combined form a parameter indicators (BISBE; BATISTA-FOGUET; CHENHALL, 2007) for evaluation, understanding and positioning opposite the informational aspects of the study. In this research, we identified categories and subcategories of analysis, which are part of the construct of the research. However, the construct was not predetermined and was adjusted during the search, according to the interpretation of the case. According to Strauss and Corbin (2008), the categories serve to improve the interpretation and organization of data. In Chart 1, the categories, subcategories, constitutive definition and authors who are part of the construct of this study.

Qualitative research produces results arising from different modes of data collection. According Strauss and Corbin (2008, p. 23), "some data can be quantified as in the case census or historical information about people or objects studied, but the bulk of the analysis is interpretive". That is, data may be gathered in several ways, such as interviews and observations which are associated with qualitative study. The use of combined methods aims to improve the quality of information (SILVERMAN, 2008; YIN, 2010;). Silverman (2008, p. 256) mentions that the goal of triangulation is the use of multiple methods of application ". The procedures used for data collection of this study were interviews, documents and observation.

Because it is a study of family business, we sought to develop semi-structured interviews with managers who are part of the family unit, in this case, represent the key informants. According to Yin (2010, p. 133), are characterized as "deep interviews" because they are usually more extensive. In SPORT Group, key informants correspond to three people within the household. In this type of research, the interviewee may suggest other managers to be interviewed, as well as other sources of evidence (YIN,

Chart 1. Research construct.

\begin{tabular}{|c|c|c|c|}
\hline Categories & Subcategories & Constitutive definition & Authors \\
\hline Business strategy & $\begin{array}{l}\text { Conservative or } \\
\text { Entrepreneurial }\end{array}$ & $\begin{array}{l}\text { 1.Environmental uncertainty } \\
\begin{array}{l}\text { 2. Information systems. } \\
\text { 3. Structure. } \\
\text { 4. Differentiation. } \\
\text { 5. Product innovation. }\end{array}\end{array}$ & $\begin{array}{l}\text { Utterback and Abernathy (1975); Porter } \\
\text { (1980); Friesen and Miller (1982); Covin } \\
\text { (1991); Naman and Slevin (1993); Lumpkin } \\
\text { and Dess (1996); OECD (2005); Almeida, } \\
\text { Machado and Panhoca (2012); Acquaah } \\
\text { (2013); Melo and Leone (2015) }\end{array}$ \\
\hline $\begin{array}{l}\text { Organizational } \\
\text { performance }\end{array}$ & $\begin{array}{l}\text { financial and non- } \\
\text { financial indicators }\end{array}$ & $\begin{array}{l}\text { ROA, ROE, EBITDA and Sales; Number } \\
\text { of Employees (2011 to 2013); \% Income } \\
\text { towards product innovation; \% Income } \\
\text { towards new processes; hours of training } \\
\text { (2011 to 2013). }\end{array}$ & $\begin{array}{l}\text { Davila (2000); Villalonga and Amit } \\
\text { (2006); Anthony and Govindarajan } \\
\text { (2002); Craig and Dibrel (2006); Silveira } \\
\text { and Oliveira (2013); Assaf Neto (2014). }\end{array}$ \\
\hline \multirow{5}{*}{ Management model } & & Controlling owner. & \multirow{5}{*}{$\begin{array}{l}\text { Gersick et al. (1997); Andres (2008), Lindow, } \\
\text { Stubner and Wullf (2010); Kowalewski, } \\
\text { Talavera and Stetsyuk (2010); Kellermanns et } \\
\text { al. (2012); Lindow (2013). }\end{array}$} \\
\hline & Ownership axis & $\begin{array}{l}\text { Corporation among brothers. } \\
\text { Cousins' consortium. }\end{array}$ & \\
\hline & Family axis & $\begin{array}{l}\text { Young family business. } \\
\text { Entry in the company. } \\
\text { Joint work. }\end{array}$ & \\
\hline & \multirow[b]{2}{*}{$\begin{array}{l}\text { Management/business } \\
\text { axis }\end{array}$} & Passing of the baton. & \\
\hline & & $\begin{array}{l}\text { Beginning. } \\
\text { Expansion/formalization. Maturity. }\end{array}$ & \\
\hline
\end{tabular}

Source: research data. 
2010). Even if the SPORT group, was suggested by respondents who were interviewed two other people who are not part of the family group, but deeply know the routine management, as work in business for 20 years. Yin (2010, p. 133-4) mentions that key informants are critical to the success of the case study, for "the researcher to provide insights on the subject and can also initiate access to corroborating sources or opposed to the evidence.

In order to ensure the reliability of information, the interviews were recorded, with the consent of respondents. After the contents of the recording was transcribed. Vieira, Major and Robalo (2009, p. 142) point out that "the interviews are recorded and transcribed to provide the researcher more reliable information than interviews that are not." After transcription, the text with the interviewees was submitted to managers for approval. Five managers were interviewed and the interviews amounted to 7 hours and 20 minutes. Interviews were conducted in June and July 2014. In addition to its interviews, other means of contact have been used, such as email, Skype and telephone in order to settle questions related to the research questions and which had not been clarified personally with the contact.

The transcript of the interviews resulted in 59 pages of records. As a result, using the technique of content analysis, to bind the text of interviews to related categories that emerged from the theoretical-methodological. For Colbari (2014, p. 247) "this is a complex task in any analysis of content, because it is what allows the organization of data". Five units were constituted in the category conservative or entrepreneurial strategy: environmental uncertainty, information systems, structure, differentiation and product innovation. The characteristics of family-run model was aligned in three categories: property, family and management/company. The Nvivo software has generated report, for encoded category with extracts from interviews that were coded in each of the categories used. Subsequent to the categorization process, promoted the analysis of the data, based on the contents and excerpts.

The use of documents in this research aims to support information highlighted in interviews on the basis of financial reports (published or not) and on information published in printed and internet sites, such as codes, regulations, brochures, and documents that describe the history and evolution of the company. Organizational performance category was identified from financial indicators calculated on the basis of the financial statements and non-financial indicators were extracted from the organizational records.

The documents consist of financial reports (published or unpublished) and information published in printed information and Internet sites, such as codes, regulations, brochures, and documents describing the history and evolution of the company. The documents used in this research were: a) history of evolution of the SPORT Group; b) annual reports of complete financial statements for the years 2011 to 2013, published in the Official State Gazette, with advice of independent auditors (big four); c) code of conduct; d) reports published on websites; e) company information extracted from the SPORT Group site; f) e-mails exchanged with the interviewees.

Observations unstructured in SPORT Group took place during the field visits, concomitant with the collection of the interview data. They were recorded in notes or diary, which, according to Gibbs (2009), are notes taken in the field (or after) where the interviews were conducted. The interviews, documents and observations are part of the field report, totaling 158 pages.

Data analysis is one of the most important stages of the study, since, according to Yin (2010, p. 155), "consists of the examination, categorization, the tab or the evidence combined otherwise to draw conclusions empirically based." In this research, the content analysis technique was used to build the text, interacting with the view of 
respondents. Practices and experiences narrated by respondents were compared with literature, in order to provide reflections on the content analysis.

\section{RESULTS}

\subsection{CHARACTERISTICS OF MANAGEMENT MODEL}

The family group that integrates the study, called anonymously as SPORT group, is one of the largest sporting goods in Brazil. The group management is in transition, with two generations in charge at strategic positions. In 2014, the SPORT Group has 16 plants in operation, 12 industrial units (South, Southeast and Northeast) in Brazil and 4 other countries. It generates about 10,000 direct jobs and 3,500 indirect jobs. The shareholding of the parent constitution is a national corporation privately held, with holding company characteristics, with activities developed through subsidiaries and joint control companies, exercised in the form of control of the economic group by a board of directors and chaired by the owner the group (REPORT FIELD, DOC 8).

Ownership of the SPORT Group is under the control of the owner / founder and members of the household. At this stage, the owner controller looks manage adequate capital and scale a partnership structure for business continuity. In the first generation companies, one of the challenges is the balance between owner autonomy and the participation of other members in control. García-Ramos and García-Ollala (2011) show that the influence of the CEO and the presence of independent directors on the boards has a positive effect on the company's performance. In companies whose owner-director has autonomy to influence and make decisions, the board has the role of advisory board, highlighted feature in the study.

One of the challenges of family businesses that have the owner-driver in the conduct of business is the passage of control and ownership to the sons (GERSICK et al., 1997).In this case, are being prepared formally considered in strategic roles. The Joint Working Family features are initially represented by the ages of the family members who are in the company>s management: the founder and owner has over 50 years old, and the younger generation - are 25 and 35 years. Among the challenges that affect the transition to the next generation, are to promote the cooperation and communication between the generations. The entry of young family managers into business management occurred naturally, since there is no admission standards of family members; however, they were driven to occupy strategic positions (footwear and apparel) in business, after developing other functions in companies. Currently, descendants exert manager's positions in different administrative units.

It is observed in the reports, family planning for entry of new members into business management. The professional preparation of family members to exercise professional duties in the organization was highlighted by the Manager 2: "I spent almost a year and a half in operation in Latin America, visiting markets, meeting several countries, consumers, customers and designing a collection that was specific to these markets [...] during this period, I traveled and met the footwear market." The academic background of the sons in the upper reaches of Directors (held in Brazil and in the United States) was essential to obtain theoretical knowledge in business and management area, stressed managers 2 and 3. In the Administration Course implementation period, they were also carried out work placements in large companies that knew the market and decisionmaking processes.

The learning and professional training of family managers in various sectors and even the experience in other large companies motivated learning and entry into the family business. This finding presents accordance with Carlock and Ward (2001), which understand that the new family generation must begin to act in the company in less 
important positions, learning the operation in various areas considered fundamental to understanding the business.

It is understood, based on reports from interviews, documents and observation during visits SPORT Group, the stage that best characterizes it is the Expansion / Formalization in accordance with structure indicated by Gersick et al. (1997). The main feature of the companies is that they have a functional organizational structure with areas, products and multi-business line. Growth is considered moderate, at around $7 \%$ per annum. Companies that are part are run by an executive board (family and nonfamily members) and managers (family and non-family members) in various business areas (footwear, apparel and accessories). Information systems are integrated in all units and adapted to the fiscal realities, legal and corporate of each country.

It is noted from the reports and documents analyzed, that the SPORT Group had expansion and growth in the business areas, private label management or licensed with the footwear industry, clothing and accessories and private label. It was found that $65 \%$ of family group $>\mathrm{s}$ business in 2014 , focus on the management of own or licensed brands, with its own brand and two international licensed brands. The segment of private label focuses $35 \%$ of businesses with leading partners in the sporting goods market, in partnerships that began over 20 years (FIELD REPORT, DOC 8).

It is noticed that, depending on the size of the company, the group follows standardized procedures and standards, as reports the Manager 2: "The processes have to be standardized, need to have that interactivity at the corporate level" or "depending on the project has a protocol to be followed". As for responsibility in functions with familiar and unfamiliar managers, both have the same powers, as highlighted by the Manager 5: family managers are usually charged as any other employee." However, says the Manager 2: "The collection ends up being the same, because each has its responsibilities and must comply with them".

It is understood that in this case, the professionalization includes rules of conduct previously defined on the basis of the decentralization of management for decision making in the intermediate levels (delegation of responsibility) and a degree of formalization of internal mechanisms for controlling the actions attributed by the division of responsibility. In addition, the centralization of the family power is represented by the posture of the founder and of the children who in some ways, feel compelled to participate and exercise activities in other areas, such as sales, purchases and contracts with partners, suppliers and customers. The results provide evidence for the family manager involvement in the role of multiple functions, CEO and President, namely, calls the responsibility for itself, to promote the growth of the company, also seeks to lead, motivate and influence people to achieve organizational objectives. While the involvement of second generation occurs more intensely to adapt to the competitive environment, indicating proactivity and corroborates Cruz and Nordqvist (2010).

Findings of the study reveal the use of controls and internal mechanisms (formal) and financial measures to assess whether the strategy is being implemented as planned, as well as assess the achievement of strategies in business environments (management of brands and private label). However, perceives the emphasis on monitoring indicators of costs more widely used in the business environment of private label, revealing a tendency to cost leadership instead of the differentiation strategy. It is understood that, in the case of SPORT Group, the parameterization of costs in the product development contributes to the fulfillment of strategies and financial objectives.

It appears, in this research, that the management model of the family business in SPORT Group has influence and legacy of its founder, beyond the values, history, goals and family commitment, which constitute integral parts in property development, family and the management/business. 


\subsection{BUSINESS STRATEGY}

We sought to identify the strategic type of conservative orientation and entrepreneurial (MILLER; FRIESEN, 1982), as subcategories listed in Chart 1. First explored up features that integrate environmental dynamism, which are the strategies related to marketing, considered by the Manager 1 as intense, according to market changes and opportunities it offers. SPORT Group outlines the marketing strategies of private label and licensed in the annual strategic planning (MANAGER 4).

Companies that innovate are likely to also act in a heterogeneous way, offering their products in several markets. SPORT Group has a network of distributors and licensees strategically located in several Latin American countries, as well as an outsourcing office in China, which supports the delivery of products to Asian countries (FIELD REPORT, DOC 8).

Growth opportunities generated by the inclusion of new markets represent ongoing challenges for enterprises faced with dynamic and hostile environments (MILLER AND FRIESEN, 1982; NAMAN;SLEVIN, 1993). Among these challenges there are the products, competition, price, government interference and the workforce. Often, companies opting for performance maximization strategy (UTTERBACK; ABERNATHY, 1975) need to develop products "with good acceptance in the market, not the company does not survive, does not grow and does not develop," emphasizes the Manager 1.

In information systems, the SPORT group, gathering information with customers and consumers occurs through companies contracted for this purpose. The monitoring of subcontractors happen at 8,000 points and indicate what the consumer buys. "We prefer instead to have a direct monthly cost, buy a targeted research to assess market share." Control systems are widely used with cost control centers, centralized accounting, monitoring of targets, evaluation of employees, internal security mechanisms and general control of the company.

SPORT Group's decision-making structure is decentralized, as the stand managers 4 and 5 . The process begins decentralized and goes to executive divisions, and various levels to build the strategy with regard to managers of factories and managers of the brands, as well as different levels of responsibility, brand managers, unit managers, line managers, departments, officers and board of directors.

Differentiation defines the attributes of the products relative to key competitors. It is characterized mainly by investment in product quality and infrastructure for the creation, development and manufacturing in SPORT Group. As stated by the Manager 3 , "the group's differential is in the operational structure. Has very large reinvestment, in structure, to upgrade the industrial parks, with innovation, this is one of the key differentiators. "The project is integrated by a prototype factory, component plant, a laboratory of physical and chemical testing and biomechanics lab. The facilities were designed in a sustainable way, recycling and use of materials, aimed at proper use of natural resources (FIELD REPORT, DOC 7, DOC 8).

Realize constant concern for manufacturing excellence in the testimonies of managers. Accordingly, the SPORT Group says its characteristic to act differently in the sports sector in the Manager 2 design when he says that, "compared to competitors, we have a superior quality product, very often intrinsic to things"; i.e. sometimes noticeable to the consumer. Among other things, the manager indicates that from the point of view of testing and product validation is the one that has biodynamics laboratory in Latin America.

Another point highlighted by managers 2 and 3 consists of factors generated by contracts in the relationship with international partners. This demand business 
generated a greater need for investment in product innovation, machinery, formulation of different materials and also motivated learning and knowledge, as well as the factories were prepared to meet a process level with more quality applied to products. As for international brands brought knowledge to SPORT Group about the importance of answering rules, quality standards, product quality and processes that have been enhanced and developed to meet the policies and standards of the partners (MANAGER 2).

The ratio of the image of own brands and licensees with competitive advantage is linked to product quality due to the creation, development and marketing, as indicated by the Manager 2: "Competitive advantage has to be related to the brand. And the brand is only built from a good product $[\ldots]$ is the fundamental principle in the relationship with the consumer and product quality then it the company has been investing heavily in innovation. "However, the competitive advantage in the business unit in private label manufacturing is in question and "have the product at a lower cost, because we have to produce and deliver at the right time," says the Manager 2.

The evaluation of product innovation strategy is in a set of three sub-categories listed in the literature as product development, processes and technology used for product development. In product development, a factor that has always been present in the relationship with partners is the constant search for projects most in need of development, which demands greater investment in innovation, machinery and formulating materials in products, and all this made the whole development process was gaining notoriety and knowledge, as well as the factories were prepared to meet a very high level of process technology applied to products (MANAGER 2). Another aspect highlighted by the Manager 3 is the relationship with international partners, since there are many inputs or materials that integrate the products produced in SPORT Group which are from abroad; however; when there is no such materials in the domestic market, the company has partnered with the national supplier to produce them.

In an innovative vision on improving processes, the widely highlighted by all managers is tool lean manufacturing, which is a very powerful tool in the product development process, and the main result is the gain in efficiency, as highlight managers 4 and 5. In terms of product development technology, SPORT Group is increasingly focused on developing forms and production processes that are more efficient, take less time and is cheaper, and it involves automation (MANAGERS 1, 2 and 3).

The innovation environment is also part of an umbrella program of innovation, which aims to project the company SPORT Group for the future (REPORT FIELD, DOC 3, p. 62). According managers 4 and 5, the innovation program indicates, for example, which is a priority, set directions and mechanisms for innovation. Based on this program, the company installed its own center of creation and development of sports shoes in one of the units of the company that is characterized by "an innovation generator environment, structured from conception to foster creativity applied to footwear, the 'design 〈end product〉 (MANAGEMENT 4).

The implementation of the center of product development creation became a "milestone divider new era for the company, because he was born with a mission to provide new and enhanced products and cutting-edge solutions for the consumer, anticipating trends" and represents " larger core development footwear in Latin America, reproduces the state of the art in terms of technology "(FIELD REPORT, DOC 7, p. 124).

Based on the documents examined in this study, there was too much emphasis on further information from the financial statements regarding the importance of innovation for products and processes and the infrastructure of innovation. On-site 
BBR

14,5

visits to administrative offices located in southern Brazil, it was noted the extensive physical infrastructure and space that the group offers.

\subsection{INTERACTION OF STRATEGY AND FAMILY MANAGEMENT MODEL WITH THE PERFORMANCE}

Although there are differences in the characterization of strategic posture by managers, in general terms, is denoted, the entrepreneurial orientation in the case study. Family businesses working in entrepreneurial environment presuppose innovation pursued continuously and aggressively through investment risk, creativity and new challenges, as well as enjoy in uncertain, dynamic, heterogeneous and hostile environments (CHANDLER, 1962; PORTER, 1980; MILLER; FRIESEN, 1982; COVIN, 1991; NAMAN; SLEVIN, 1993;ZAHRA, 2005; CRAIG; DIBRELL, 2006).

It appears the occurrence of differentiation and product innovation in SPORT Group in line with the dynamic, heterogeneous and hostile environment, as advocated Miller and Friesen (1982). Innovation occurs proactively, mainly directed to create new products and new demands from a market requirement (CAMERON, 1986; BRITO; BRITO; MORGANTI; 2009; SILVEIRA; OLIVEIRA, 2013). This is essentially the strategy of continuity and growth, which is peculiar family of companies with entrepreneurial characteristics (LUMPKIN; DESS, 1996; ZAHRA; SHARMA, 2004). To do so, make investments in infrastructure and hire specialized people (mostly designs) to develop new products, evidence also reported by Davila, Foster and Li (2009).

It appears in this case that the family entrepreneur is motivated by the desire for survival and continuity and influence the management of their businesses and raising their sons to grow and prospective their careers in that business environment. However, the second generation appears to establish a new dynamic to work for the family business, supported by contemporary knowledge of new technologies, organizational learning opportunities and adaptability to experience new managerial experiences. In designing Sciascia and Mazzola (2008), the academic and professional education of family members should be designed in advance and preferably outside the company so they can develop their own relationships to identify and exploit new business opportunities.

It is also observed in case of the analysis results, a close interface with the innovation potential consumer, as evidenced by the Manager 2: "In this business unit [trademark] is indirectly involving the consumer [...] the fundamental principle is value to the consumer and the product, then it is that the company has been investing heavily in innovation. "SPORT Group seeks product innovation particularly regarding creating new models, design and appearance of the product and issues linked to health, wellbeing and comfort. It appears in the account, which in an indirect relationship with the consumer family manager's reaction power is proactive, i.e. responds to the uncertain environment and promotes alignment between strategy and structure, to seek survival and superior performance (ASTLEY; VAN DE VEN, 1983; DRAZIN; VAN DE VEN, 1985; LINDOW, 2013).

While not the "change" a specific category of this study, it emerged by endogenous and exogenous characteristics of the organizational environment, i.e. "change takes the form of adaptation" (ASTLEY; VAN DE VEN, 1983, p 83) in the management model of the family business. It is understood that organizations that adopt entrepreneurial orientation generate continuous and significant changes in the environment, and in the process to create and innovate is ever-changing and the strategic adjustment becomes a condition of survival. The relationship between business strategy and financial results SPORT Group, it appears that profitability decreased and sales increased in the years under study. However, although sales revenue was higher in the years under review 
(2011 <> 2013), around 25\%, the operating margin decreased approximately $70 \%$ over the same period. The results empirical are consistent Silveira and Oliveira (2013) in the relation of innovation with the growth of the company.

In this case, the company invested significantly over the past three years, $\mathrm{R} \&$ $\mathrm{D}$, infrastructure and new technologies (5\% of sales) and new processes $(1.8 \%)$, representing percentages, as indicated by Davila (2000). Even if financial performance is positive, it was not expected by managers (FIELD REPORT, DOC 8, p. 113).

It appears in this case that the SPORT Group made significant investments in product innovation; however, the structure may not have responded favorably, demonstrating that performance can lead to the need to adapt the organizational structure (DONALDSON, 2001). The Manager 2 mentions:

[...] In the last six months, we are making an almost complete restructuring in the development of shoes, and then I joined the project to control all this [second generation]. We are restructuring many processes because we had several weaknesses, communication and efficiency of processes across products, trading markets between and among products and factories.

In an adaptation of the adjustment model, are presented the contingency factors evidenced by the case study object (Figure 1). It is inferred that the analysis of the relationship between strategy and performance based on financial indicators, there are indications adjustments in the organization, as says the Manager 2: "We are executing a bold and intense rationalization program and inventory optimization and structures in order to leave more agile operation, lighter, more flexible, more competitive, stronger changing scenarios."

Another factor in the need to adjust the organizational structure was indicated in the organizational records and documents consulted. SPORT Group has a 75\% workforce in the domestic market and $25 \%$ in the foreign market (approximate percentages). It was found to reduce the number of employees in Brazil around 20\% (2011> 2013), however, by internal decisions did not accomplish a greater reduction in the workforce to adapt to the economic crisis, in this case, increased account Cost of Goods Sold and consequently reduced the operating margin in the years 2012 and 2013.

It is inferred that such a decision to preserve jobs in the face of unfavorable market situation, is premised on that investment in intellectual capital can be a competitive advantage differential exploited as a resource. It was found that the SPORT Group made significant investment in staff training in 2011 to 2013, around 40 hours per employee year. This indicator reveals accordance with Sirmon and Hitt (2003) that among the attributes that indicate competitive advantage of family businesses and to differentiate them from unfamiliar companies are investing in human capital. It is understood that strategy to retain talent and functional skills are critical for survival and continuity of family businesses.

It appeared that from the information generated by the managerial control systems, there was the need for the structure adjustments occurring after evaluation of the performance and strategic objectives, leading to operational changes that included the adequacy of internal variables related to structure operational, including the redefinition of people and management positions, including family members, as pointed out in the statements.

It is inferred that the adaptive adjustment (Figure 1) is possible because, in business management, engages a family-run model in which the owner-driver is ahead of management as CEO, while the second generation (descendants) is the continuity of the company and consequently the implementation of the strategies. The adjustment occurs, however, when there is congruence between managers and their work environment and 
BBR

14,5

505

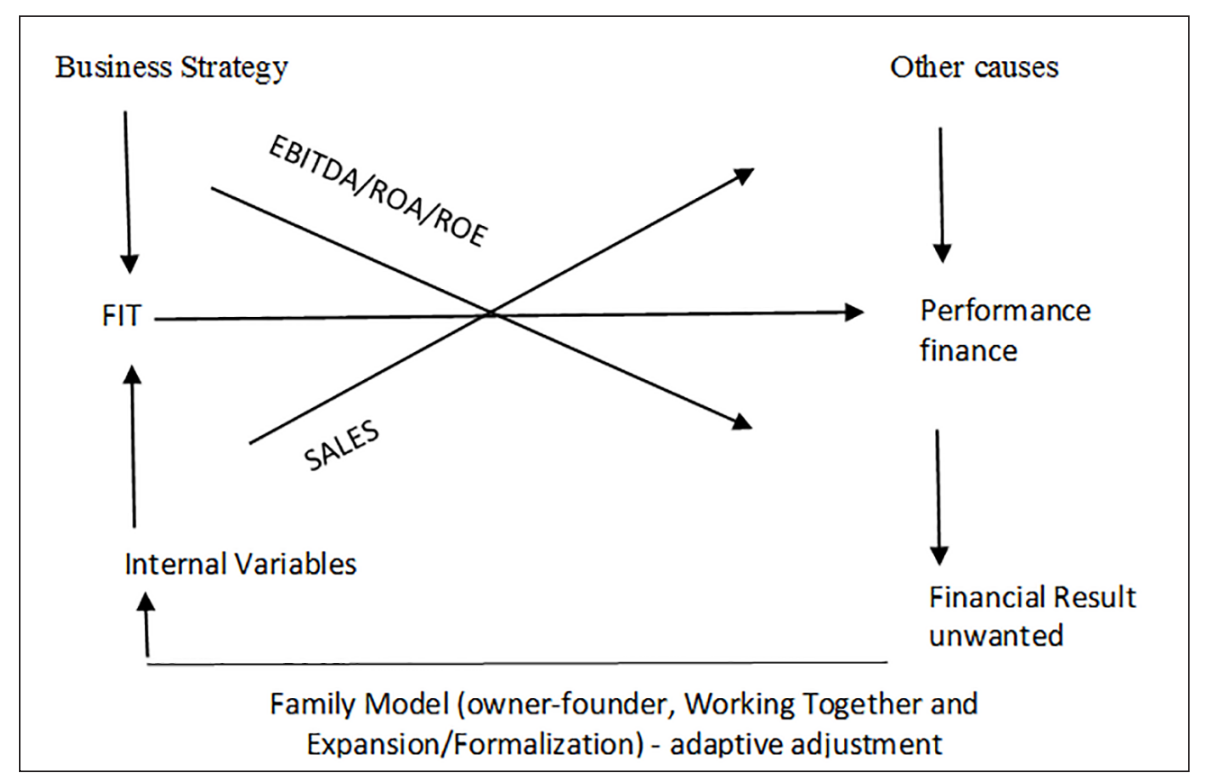

Source: adapted based on Donaldson (2001).

Figure 1. Contingent adjustment model Adaptation.

between managers and their family environment. This finding is consistent with the literature (ROTHAUSEN, 2009).

Rothausen (2009) states that the adaptive adjustment in family businesses is possible because: a) values and organizational culture are shared by the leadership style and behavioral rules governing the setting of the family and business duality; b) flexibility to family manager to adapt to family activities as well as tangible rewards (remuneration) and intangible (personal fulfillment and social status); c) relationship between generations, gives opportunity to transfer knowledge and financial resources that can affect the organization with the passage of time; d) investment in human capital, social and financial impact positively to organizational effectiveness.

In the case study in question, the complexity of operating procedures brought a robust and expensive because of the strategy to grow and compete in international markets. Porter (1980) states that to do so, companies need to have investment in research, innovation, design and product development. Thus, the management realized it more difficult to manage, so decided from 2014 to develop actions to adjust the structure to become more competitive, that is, realized the need for a change concerning the internal structure of the governing body and internal procedures. The «procedures need to be simpler, practical and economical,» says the Manager 4.

Thus, there are indications of proposition research that fit the business strategy and family business management model positively affect organizational performance. The results show accordance with Zahra (2005) and Amit and Villalonga (2006), Andres (2008),Lindow, Stubner and Wullf (2010) and Kowalewski, Talavera and Stetsyuk (2010), indicating the influence of the family, in particular the direct involvement of the owner-controller and sons, who play a key role in the realization of the strategic fit , aiming at the promotion of superior performance.

The results indicate that the contingent interaction of variables (strategy, structure, management processes and environment) are observed by family management to promote the strategic adjustment. The results show compliance with Cruz and Nordqvist (2010). Cruz and Nordqvist (2010) are supported by insights on entrepreneurship literature (LUMPKIN; DESS, 1996) and suggest that entrepreneurship level of a company is influenced by its internal and external environment. The results indicate 
that the perception of the competitive environment and the entrepreneurial orientation are correlated differently in family businesses, depending on the generation in charge, and are generally stronger in the second-generation family business.

It is understood that in the case under study, the entrepreneurial orientation and family influence plays an important role for the realization of structural and strategic fit and, in turn, to achieve higher performance. This observation aligns with that recommended in the literature, indicating the influence of the family (owner-driver and working together) to adjust to the competitive environment (HIENERTH; KESSLER, 2006; LINDOW; STUBNER; WULF, 2010). Again, the family-run model allows more flexibility in decisions and hence less bureaucracy, greater flexibility and simplify operations, most informal communication, greater organizational learning. The finding corroborates the above by Covin and Slevin (1989), claim that the interaction between the entrepreneurial orientation and the organic was significantly correlated with the company's performance.

\section{CONCLUSIONS}

The objective of this research was to analyze how occurs the interaction of business strategy with organizational performance in the study object family business and points to family influence as an adjustment factor between strategy and performance. The company adopts a position to consolidate the market through differentiation and innovation of products, suggesting entrepreneurial orientation. The study was developed as part of a large Brazilian family company with headquarters in the south of the country.

Consists of statements and documents analyzed that in the last three years, the SPORT Group made significant investments in infrastructure for R \& D and innovation, adopting processes and technology leadership; however, the economic and financial performance in the review period, it was not desired by management. The organization has made changes and internal adjustments, for example: restructuring industries, repositioning own brands and licensed and reducing operating costs. In this sense, there is structural adjustment with family influence to adapt and repositioning of the persons occupying strategic positions in the group. Such objective setting implement the strategies and improve financial performance. In this case, the CEO and ownercontroller aligns family interests (ownership and continuity) with business objectives, as well as familiar and unfamiliar managers in the execution and control of operational goals and results.

While not changing a specific category of this study, it emerged by endogenous and exogenous characteristics of the study environment. It is noticed that the family business configuration model (Owner Controller, Joint Working and Expansion / Formalization) in this case is an important factor for the structural and strategic adjustment and to carry out the changes in the organization, which indicates confirmation proposition of the study. Thus, there was greater flexibility in decision-making, flexibility in processes and streamlining operations, the results of which are reported in other studies: Lindow, Stubner and Wulf (2010); Kellermans et al. (2012); Lindow (2013) and Craig, Dibrel and Garret (2014).

In this case of analysis, the contingent adjustment represented a structural change of the decision-making process, restructuring departments and sectors, repositioning managers and brand and reducing operating costs, denoting more conservative attitude. In this regard, note that the setting for the family business management (ownercontroller, joint work and management/company) has influence when proposes and carries out necessary changes in organizational structure. It is noted that the adequacy 
BBR

of the organization to its environment does Contingency Theory part of functionalism adapted (DONALDSON, 2001). It is understood that the involvement and influence of family on the property and management are relevant factors that determines the degree of centralization of decision making in the company.

The findings of this research contributes to company literature familiar to demonstrate involvement and influence of family (first and second generation) to adapt to the competitive environment, through the strategy of differentiation and product innovation, mainly in business processes and environment aspects little evidenced by previous studies (PADILLA; DIEGUEZ; MORENO, 2015). The transmission of knowledge and experience from the first to second generation is an important factor to manage the organization, once it comes to business knowledge, standards, principles, values and beliefs, principles of family unity, revealing the family business literature features (NÓBREGA; HOFFMANN, 2014; PADILLA, DIEGUEZ; MORENO, 2015). In addition, the preparation of the next generation about academic issues, new markets and experience in other non-family business has proved as a strategic imperative for continuity and perpetuation of the family business.

The research design strategies impose limitations to the results, which may be the subject of further investigations. The family involvement in management, it is suggested to use other models with the addition of dimension culture, essential for the assessment of family interaction and business. The construct of categorical assigned in this research can be applied to other organizations and will help increase the validity of the observed results. The findings in other studies may contribute to the theoretical generalization and complement the theoretical development strategy and performance in family firms.

\section{REFERENCES}

ACQUAAH, M. Business strategy and competitive advantage in family businesses in Ghana: the role of social networking relationships. Journal of Developmental Entrepreneurship, v. 16, n. 1, p. 103-26, 2011.

ACQUAAH, M. Management control systems, business strategy and performance: A comparative analysis of family and non-family businesses in a transition economy in sub-Saharan Africa. Journal of Family Business Strategy, v. 4, n. 2, p. 131-46, 2013.

ANDRES, C. Large shareholders and firm performance - an empirical examination of founding-family ownership. Journal of Corporate Finance, v. 14, n. 4, p. 431-45, 2008.

ASSAF NETO, A. Finanças corporativas e valor. 7.ed. São Paulo: Atlas, 2014.

ASTLEY, W. G.; VAN DE VEN, A. H. Central perspectives and debates in organization theory. Administrative Science Quarterly, p. 245-73, 1983.

BISBE, J.; BATISTA-FOGUET, J.-M.; CHENHALL, R. Defining management accounting constructs: a methodological note on the risks of conceptual misspecification. Accounting, Organizations and Society, v. 32, n. 7, p. 789-820, 2007.

BURKART, M.; PANUNZI, F.; SHLEIFER, A. Family firms. The Journal of Finance, v. 58, n. 5, p. 2167202, 2003.

BRITO, E. P. Z.; BRITO, L. A. L.; MORGANTI, F. Inovação e o desempenho empresarial: lucro ou crescimento?. RAE-eletrônica, v. 8, n. 1, art.7, p. 1-24, 2009.

CAMERON, K. S. Effectiveness as paradox: Consensus and conflict in conceptions of organizational effectiveness. Management Science, v. 32, n. 5, p. 539-53, 1986.

CARNEIRO, J. M. T.; CAVALCANTI, M. A. F. D.; SILVA, J. F. Porter revisitado: análise crítica da tipologia estratégica do mestre. Revista de Administração Contemporânea, v. 1, n. 3, p. 7-30, 1997.

CARLOCK, R.S.; WARD, J. L. Strategic planning for the family business: Parallel planning to unify the family and business. Palgrave Macmillan, 2001.

CHANDLER, A. D. Strategy and Structure: chapters in the history of the american industrial enterprise. Cambridge, Massachussets: MIT Press, 1962.

COLBARI, A. A análise de conteúdo e a pesquisa empírica qualitativa. In.: SOUZA, E, M. (Org.). Metodologias e analíticas qualitativas em pesquisa organizacional: uma abordagem teóricoconceitual. Espírito Santo: EDUFES, 2014. 
COVIN, J. G. Entrepreneurial versus conservative firms: A comparison of strategies and performance. Journal of Management Studies, v. 28, n. 5, p. 439-62, 1991.

COVIN, J. G.; SLEVIN, D. P. Strategic management of small firms in hostile and benign environments. Strategic Management Journal, v. 10, n. 1, p. 75-87, 1989.

CRAIG, J. B.; DIBRELL, C.; GARRETT, R. Examining relationships among family influence, family culture, flexible planning systems, innovativeness and firm performance. Journal of Family Business Strategy, v. 5, n. 3, 2014.

CRAIG, J.; DIBRELL, C. The natural environment, innovation, and firm performance: A comparative study. Family Business Review, v. 19, n. 4, p. 275-88, 2006.

CRUZ, C.; NORDQVIST, M. Entrepreneurial orientation in family firms: A generational perspective. Small Business Economics, v. 38, n. 1, p. 33-49, 2010.

DAVILA, A. An empirical study on the drivers of management control systems' design in new product development. Accounting, Organizations and Society, n. 25, p. 383-409, 2000.

DAVILA, A.; FOSTER, G.; LI, M. Reasons for management control systems adoption: Insights from product development systems choice by early-stage entrepreneurial companies. Accounting, Organizations and Society, v. 34, n. 3, p. 322-47, 2009.

DAVILA, T.; EPSTEIN, M. J.; SHELTON, R. As regras da inovação. Porto Alegre: Bookman, 2007.

DONALDSON, L. The Contingency Theory of Organizations. United States of America: Sage Publications, Inc., 2001.

DRAZIN, R.; VAN DE VEN, A. H. Alternative forms of fit in contingency theory. Administrative Science Quarterly, v. 30, p. 514-39, 1985.

FIELD REPORT. Report Company Sport. Observations, interviews and documents. 2015.

GARCÍA-RAMOS, R.; GARCÍA-OLALLA, M. Board characteristics and firm performance in public founder-and non founder-led family businesses. Journal of Family Business Strategy, v. 2, n. 4, p. 220-231, 2011.

GERSICK, K. E. et al. De geração para geração: ciclos de vida das empresas familiares. São Paulo: Negócio, 1997.

GIBBS, G. Análise de dados qualitativos. In: FLICK, U. (Coord.). Coleção pesquisa qualitativa. Porto Alegre: Bookman: Artmed, 2009.

GONÇALVES, S.As empresas familiares no Brasil. Revista de Administração de Empresas, v. 40, n. 1, p. 7-12, 2000.

GOVINDARAJAN, V. A contingency approach to strategy implementation at the business-unit level: integrating administrative mechanisms with strategy. Academy of management Journal, v. 31, n. 4, p. 828-53, 1988.

HABBERSHON, T. G.; WILLIAMS, M. L. A resource-based framework for assessing the strategic advantages of family firms. Family Business Review, v. 12, n. 1, p. 1-25, 1999.

HAMBRICK, D. C. High profit strategies in mature capital goods industries: a contingency approach. Academy of Management Journal, v. 26, n. 4, p. 687-707, 1983.

HIENERTH, C.; KESSLER, A. Measuring success in family businesses: The concept of configurationally fit. Family Business Review, v. 19, n. 2, p. 115-34, 2006.

KELLERMANNS, F.W. et al. Innovativeness in family firms: A family influence perspective. Small Business Economics, v. 38, n. 1, p. 85-101, 2012.

KOWALEWSKI, O.; TALAVERA, O.; STETSYUK, I. Influence of family involvement in management and ownership on firm performance: evidence from Poland. Family Business Review, v. 23, n.1, p. 45-59, 2010.

KPMG. Questões sobre empresas familiares: fomentando o crescimento das empresas familiares por meio de investidores individuais. 2014. Disponível em: http://www.kpmg.com/br/pt/estudos_analises/ artigosepublicacoes/paginas/empresas-familiares.aspx. Acesso em 08 fev. 2015.

LINDOW, C. A Strategic Fit Perspective on Family Firm Performance. Deutsche: Springer Gabler, 2013.

LINDOW, C. M.; STUBNER, S.; WULF, T. Strategic fit within family firms: The role of family influence and the effect on performance. Journal of Family Business Strategy, v. 1, n. 3, p. 167-78, 2010.

LUMPKIN, G. T.; DESS, G. G. Clarifying the entrepreneurial orientation construct and linking it to performance. Academyof management Review, v. 21, n. 1, p. 135-72, 1996.

MELO, M. A.; LEONE, R. J. G. Alinhamento entre as Estratégias Competitivas e a Gestão de Custos: Um Estudo em Pequenas Empresas Industriais do Setor de Transformação. Brazilian Business Review, v. 12, n. 5, p. 83-104, 2015. 
BBR

14,5

MILLER, D.; FRIESEN, P. H. Innovation in conservative and entrepreneurial firms: two models of strategic momentum. Strategic Management Journal, v. 3, n. 1, p. 1-25, 1982.

NAMAN, J. L.; SLEVIN, D. P. Entrepreneurship and the concept of fit: a model and empirical tests. Strategic Management Journal, v. 14, n. 2, p. 137-53, 1993.

NÓBREGA, G. J.; HOFFMANN, V. E. Family businesses and the creation of entrepreneurship through their internal resources. Revista Pensamento Contemporâneo em Administração, v. 8, n. 2, p. 92-105, 2014.

ORGANISATION FOR ECONOMIC CO-OPERATION AND DEVELOPMENT. Oslo manual: Guidelines for collecting and interpreting innovation data. European Commission: OECD Publishing, 2005.

PADILLA-MELÉNDEZ, A.; DIEGUEZ-SOTO, J.; MORENO, A. G. Pesquisa empírica sobre Inovação na Empresa Familiar: revisão de literatura e proposta de estrutura integrativa. Revista Brasileira de Gestão de Negócios, v. 17, n. 56, p. 1064-1089, 2015.

PORTER, M. E. Competitive strategy. New York: Free Press, 1980.

PRIETO, V. C.; CARVALHO, M. M. de; FISCHMANN, A.A. Análise comparativa de modelos de alinhamento estratégico. Production, v. 19, n. 2, p. 317-331, 2009.

ROTHAUSEN, T. J. Management Work-Family Research and Work-Family Fit Implications for Building Family Capital in Family Business. Family Business Review, v. 22, n. 3, p. 220-234, 2009.

SCHUMPETER, J.A.The theory of economic development: An inquiry into profits, capital, credit, interest, and the business cycle. United States of América: Transaction Publishers, 1934.

SCIASCIA, S.; MAZZOLA, P. Family involvement in ownership and management: Exploring nonlinear effects on performance. Family Business Review, v. 21, n. 4, p. 331-45, 2008.

SCIASCIA, S.; MAZZOLA, P.; KELLERMANNS, F.W. Family management and profitability in private family-owned firms: introducing generational stage and the socioemotional wealth perspective. Journal of Family Business Strategy, v. 5, n. 2, p. 131-137, 2014.

SEBRAE. No Brasil 90\% das empresas são familiares. 2005. Disponível em: <http://www.sebrae-sc. com.br/newart/default.asp?materia=10410>. Acesso em: 11 jun. 2013.

SILVERMAN, D. Interpretação de dados qualitativos métodos para análise de entrevistas, textos e interações. 3. ed. Porto Alegre: Artmed, 2008.

SILVEIRA, J. D. C. A.; OLIVEIRA, M. A. Inovação e desempenho organizacional: um estudo com empresas brasileiras inovadoras. Sociedade, Contabilidade e Gestão, v. 8, n. 2, p. 64-88, 2013.

SIRMON, D. G.; HITT, M. A. Managing resources: Linking unique resources, management, and wealth creation in family firms. Entrepreneurship Theory and Practice, v. 27, n. 4, p. 339-58, 2003.

STRAUSS, A. L.; CORBIN, J. M. Pesquisa qualitativa: técnicas e procedimentos para o desenvolvimento de teoria fundamentada. 2. ed. Porto Alegre: Artmed; Bookman, 2008.

UTTERBACK, J. M.; ABERNATHY, W. J. A dynamic model of process and product innovation. Omega, v. 3, n. 6, p. 639-56, 1975.

VENKATRAMAN, N.; CAMILLUS, J.C. Exploring the concept of fit in strategic management. Academy of Management Review, v. 9, n. 3, p. 513-525, 1984.

VENTER, E.; BOSHOFF, C.; MAAS, G. The influence of successor-related factors on the succession process in small and medium-sized family businesses. Family Business Review, v. 18, n. 4, p. 283303, 2005.

VIEIRA, R.; MAJOR, M. J.; ROBALO, R. Investigação qualitativa em contabilidade. In: MAJOR, M. J.; VIEIRA, R. Contabilidade e controle de gestão. Lisboa: Escolar, 2009.

VILLALONGA, B.; AMIT, R. How do family ownership, control and management affect firm value? Journal of Financial Economics, v. 80, n. 2, p. 385-417, 2006.

YIN, R. K. Estudo de caso: planejamento e métodos. 4. ed. Porto Alegre: Bookman, 2010.

ZAHRA, S. A. A theory of international new ventures: a decade of research. Journal of International Business Studies, v. 36, n. 1, p. 20-8, 2005.

ZAHRA, S. A.; SHARMA, P. Family Business Research: A Strategic Reflection. Family Business Review, v. 17, p. 331-46, 2004.

ZELLWEGER, T. Time horizon, costs of equity capital and generic investment strategies of firms. Family Business Review, v. 20, n.1, p. 1-15, 2007.

ZELLWEGER, T. M.; NASON, R. S.; NORDQVIST, M. From longevity of firms to transgenerational entrepreneurship of families introducing family entrepreneurial orientation. Family Business Review, v. 25, n. 2 , p. $136-155,2012$. 